\title{
Reaction of Curium(III) Ions with Oxo-species in Alkali Chloride Melts
}

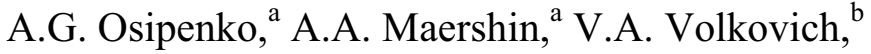 \\ M.V. Kormilitsyn, ${ }^{a}$ and A.V. Bychkov ${ }^{a}$ \\ ${ }^{a}$ Research Institute of Atomic Reactors, Dimitrovgrad, 433510, Russia \\ ${ }^{b}$ Department of Rare Metals and Nanomaterials, Ural Federal University, \\ Ekaterinburg, 620002, Russia
}

\begin{abstract}
Electronic absorption spectra of curium(III) chloro-species were measured in $3 \mathrm{LiCl}-2 \mathrm{KCl}$ (at $450{ }^{\circ} \mathrm{C}$ ) and $\mathrm{NaCl}-2 \mathrm{CsCl}$ (at 550, 650 and $750{ }^{\circ} \mathrm{C}$ ) eutectic melts and the molar absorption coefficients determined. The effect of oxide species addition to the melt on the absorption spectra of curium was studied. A new species, evident from the absorption bands around $360 \mathrm{~nm}$, is formed when barium oxide is dissolved in the melt or $\mathrm{O}_{2}-\mathrm{Cl}_{2}$ or $\mathrm{Ar}-\mathrm{HCl}-\mathrm{H}_{2} \mathrm{O}$ gas mixtures bubbled through. This species is ascribed to soluble curium oxychloride. It does not react with chlorine bubbled through the melt unless there is carbon present.
\end{abstract}

\section{Introduction}

Pyrochemical reprocessing of spent nuclear fuels employing alkali metal chloride based melts is considered as a possible alternative to the existing extraction technology. Curium is one of the minor actinides present in the spent fuel and understanding its behavior in molten salts is important for designing a feasible process. The stable oxidation state of curium in chloride melts is +3 . The electrochemical studies in NaCl$2 \mathrm{CsCl}$ melt showed that $\mathrm{CmCl}_{6}{ }^{3-}$ species undergo a one-step three-electron reduction to $\mathrm{Cm}(0)(1)$. No evidence of higher oxidation states of curium in this melt was obtained.

Similar to lanthanides, trivalent curium forms a stable oxychloride $\mathrm{CmOCl}, e . g$., by reacting $\mathrm{CmCl}_{3}$ (or $\mathrm{Cm}_{2} \mathrm{O}_{3}$ ) at $500-600{ }^{\circ} \mathrm{C}$ with vapor in equilibrium with a $10 \mathrm{M}$ solution of $\mathrm{HCl}$ (2). The crystal structure of $\mathrm{CmOCl}$ has also been characterized (2). Formation of curium oxychloride is possible in molten salts. The interaction of $\mathrm{Cm}$ (III) chloride with oxygen species in fused alkali chlorides was recently studied electrochemically (3). Depending on the concentration of oxide ions, melt composition and temperature curium oxychloride or oxide may be formed:

$$
\begin{gathered}
\mathrm{Cm}^{3+}+\mathrm{O}^{2-}+\mathrm{Cl}^{-} \rightarrow \mathrm{CmOCl} \\
2 \mathrm{Cm}^{3+}+3 \mathrm{O}^{2-} \rightarrow \mathrm{Cm}_{2} \mathrm{O}_{3}
\end{gathered}
$$

Electronic absorption spectroscopy can be applied for studying behavior of $\mathrm{Cm}$ (III) ions having $5 f^{7}$ electronic configuration. Electronic absorption spectra (EAS) of Cm(III) and (IV) species have mostly been studied in solutions and in the solid state (4-8). A recent EXAFS spectroscopy study showed that in dilute aqueous chloride solutions $(0.25$ $\mathrm{M} \mathrm{HCl}$ ) $\mathrm{Cm}^{3+}$ ions are surrounded by $\mathrm{H}_{2} \mathrm{O}$ molecules with the hydration number just over ten (9). In concentrated $(10.5$ and $12.3 \mathrm{M})$ solutions of $\mathrm{LiCl}$ the hydration number decreases to 6.6-6.1 and $\mathrm{Cl}^{-}$enters the inner coordination sphere with the coordination 
number 2.1-2.4. A very limited body of work exists on the spectra of curium in melts. EAS of molten $\mathrm{Cs}_{2} \mathrm{NaCmCl}_{6}$ were recorded at $830{ }^{\circ} \mathrm{C}$ as well as the spectra of solutions of curium(III) chloride in $(\mathrm{Li}-\mathrm{Na}-\mathrm{K}) \mathrm{F}$ and $(\mathrm{Li}-\mathrm{Na}-\mathrm{K})(\mathrm{Cl}-\mathrm{F})$ mixtures at $650{ }^{\circ} \mathrm{C}(10,11)$. In all molten salt systems studied the spectra were interpreted as arising from sixcoordinated octahedral $\mathrm{Cm}$ (III) species. In the present work the electronic absorption spectroscopy was employed to study the reactions of $\mathrm{Cm}(\mathrm{III})$ containing chloride melts with oxygen species.

\section{Experimental}

The experiments were conducted in two eutectic melts, $\mathrm{NaCl}-2 \mathrm{CsCl}$ at $550-750{ }^{\circ} \mathrm{C}$ and $3 \mathrm{LiCl}-2 \mathrm{KCl}$ at $450{ }^{\circ} \mathrm{C}$. Curium-244 isotope was used throughout the study. The starting curium(III) chloride containing melts were prepared by chlorinating curium dioxide (purified from plutonium and americium using standard techniques) in a chosen solvent melt. Owing to relatively low molar absorption coefficients of $\mathrm{Cm}$ (III) in fused chlorides the concentration of curium in the melts used here for the spectroscopy measurements varied from 0.1 to $0.3 \mathrm{~mol} / 1$ and the total amount of curium used in a single experiment ranged from 0.10 to $0.37 \mathrm{~g}$. The melts were held in silica cells with $1 \mathrm{~cm}$ path length optical parts attached to the bottom. The cells accommodated gas bubbling tubes and other required accessories. All manipulations with the experimental cells were conducted in a negative pressure glove box with an optical furnace attached to the bottom. The EAS were measured using a double channel fiber optic spectrometer AvaSpec-2048-2 (Avantes).

Oxide species were introduced into the melt by adding barium oxide or bubbling gaseous mixtures $\left(\mathrm{Cl}_{2}-\mathrm{O}_{2}\right.$ or $\left.\mathrm{HCl}-\mathrm{H}_{2} \mathrm{O}-\mathrm{Ar}\right)$ with various partial pressures of the components according to the following equilibria:

$$
\begin{gathered}
1 / 2 \mathrm{O}_{2(\mathrm{~g})}+2 \mathrm{Cl}^{-} \leftrightarrow \mathrm{O}^{2-}+\mathrm{Cl}_{2(\mathrm{~g})} \\
2 \mathrm{H}_{2} \mathrm{O}_{(\mathrm{g})}+4 \mathrm{Cl}^{-} \leftrightarrow \mathrm{O}^{2-}+4 \mathrm{HCl}_{(\mathrm{g})}
\end{gathered}
$$

\section{Results and discussion}

\section{$\underline{\text { Absorption spectra of } \mathrm{Cm}(\mathrm{III}) \text { ions in fused chlorides }}$}

The EAS of curium(III) chloride solutions in $\mathrm{NaCl}-2 \mathrm{CsCl}$ and $3 \mathrm{LiCl}-2 \mathrm{KCl}$ eutectic melts are shown in Figure 1. Profile of the spectral curves and the absorption bands present correspond to those reported for six-coordinated $\mathrm{CmCl}_{6}{ }^{3-}$ species (11). Primary maxima in the spectra are situated at ca. 435-445, 405 and 380-390 nm. The EAS recorded in $\mathrm{NaCl}-2 \mathrm{CsCl}$ melt at $550-750{ }^{\circ} \mathrm{C}$ and in $3 \mathrm{LiCl}-2 \mathrm{KCl}$ melt at $450{ }^{\circ} \mathrm{C}$ are similar, with the molar absorption coefficient somewhat increasing from $\mathrm{NaCl}-2 \mathrm{CsCl}$ to $3 \mathrm{LiCl}-$ $2 \mathrm{KCl}$. Weak absorption peaks around $500 \mathrm{~nm}$ resulted from a minor americium(III) impurity present. The concentration of americium can be estimated from the known molar absorption coefficients of Am(III) ions in alkali chloride melts (12). In the present study the Am : Cm molar ratio in the melts did not exceed 0.004 .

The absorption spectra of $\mathrm{CmCl}_{6}{ }^{3-}$ complex ions were resolved into individual bands and an example is given in Figure 2 with the electronic transitions corresponding to the individual bands marked. The transitions observed arise from the ground ${ }^{8} \mathrm{~S}_{7 / 2}$ state. 


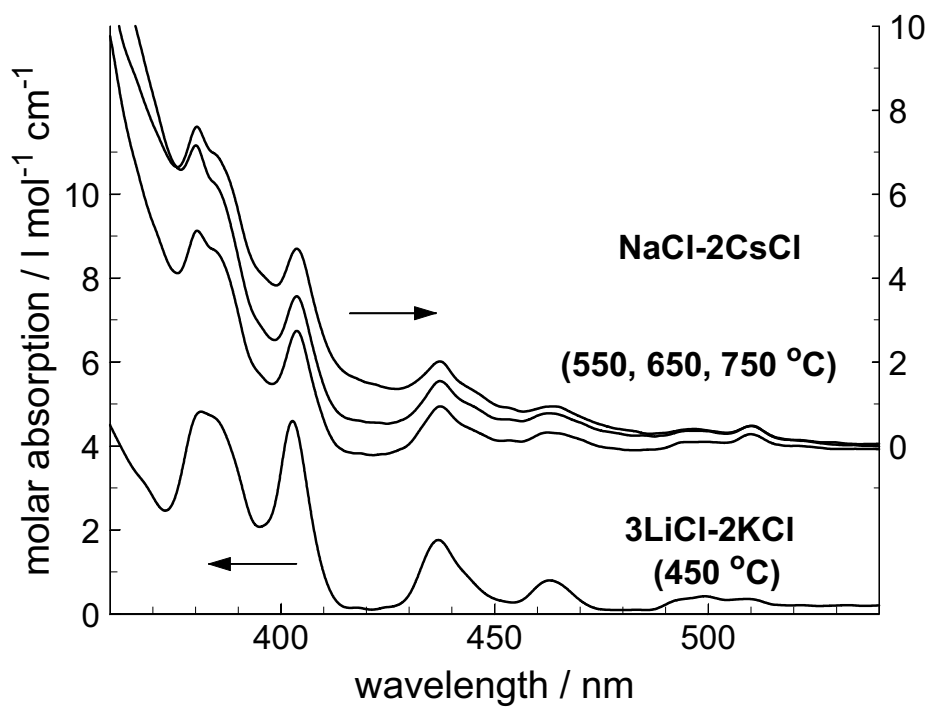

Figure 1. EAS of $\mathrm{Cm}(\mathrm{III})$ chloro-species in $\mathrm{NaCl}-2 \mathrm{CsCl}$ and $3 \mathrm{LiCl}-2 \mathrm{KCl}$ eutectic melts. Temperature (top to bottom): 550, 650, 750 , and $450{ }^{\circ} \mathrm{C}$.

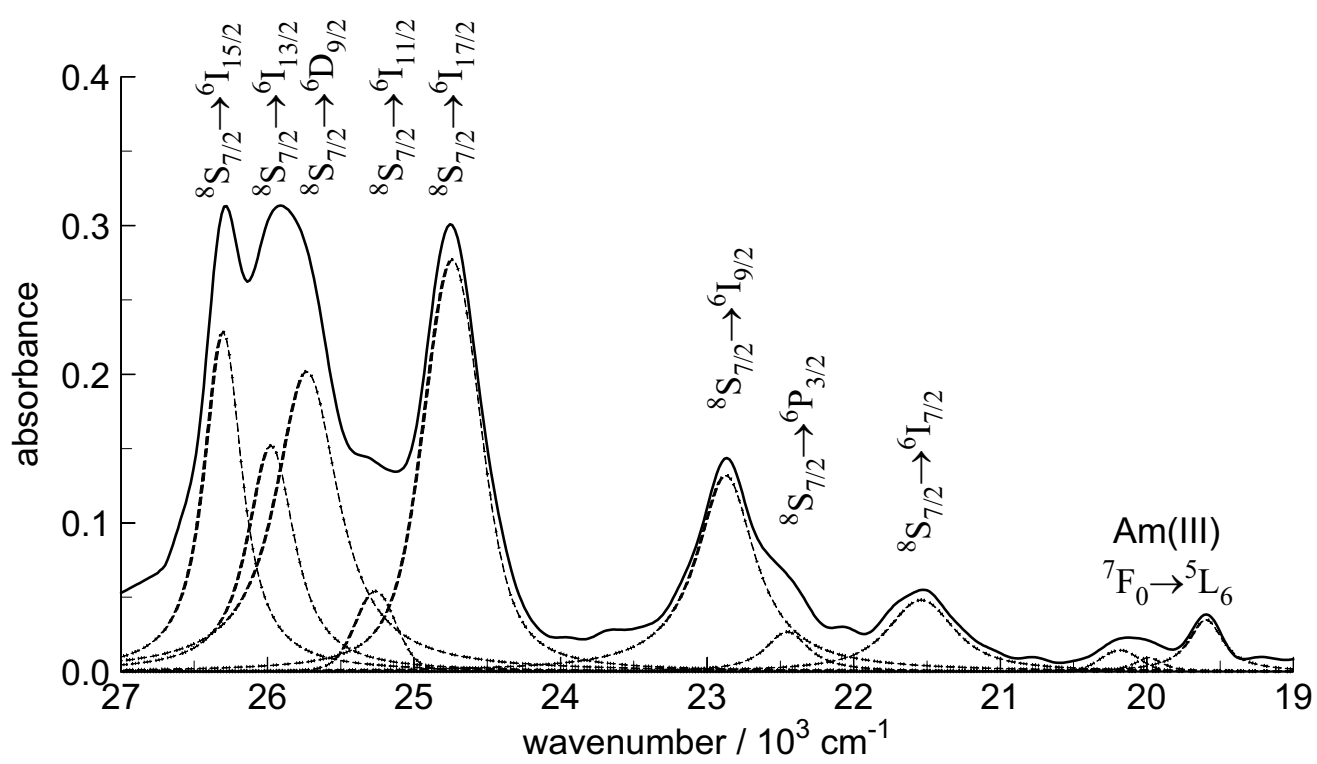

Figure 2. Electronic absorption spectrum of $\mathrm{CmCl}_{6}{ }^{3-}$ in $\mathrm{NaCl}-2 \mathrm{CsCl}$ eutectic melt at $550{ }^{\circ} \mathrm{C}$ resolved into individual bands (background subtracted) with the corresponding electronic transitions marked. $\left[\mathrm{Cm}^{3+}\right]=0.115 \mathrm{~mol} / 1$. Peaks around $19500-20500 \mathrm{~cm}^{-1}$ arise due to some Am impurity present in starting curium oxide.

The $\mathrm{Cm}-\mathrm{Cl}$ distance $\left(\mathrm{R}_{\mathrm{Cm}-\mathrm{Cl}}\right)$ in $\mathrm{CmCl}_{6}{ }^{3-}$ was estimated employing a procedure described by Barbanel (11). In $3 \mathrm{LiCl}-2 \mathrm{KCl}$ melt at $450{ }^{\circ} \mathrm{C} \mathrm{R}_{\mathrm{Cm}-\mathrm{Cl}}$ equaled to $c a$. $0.275 \mathrm{~nm}$. In NaCl-2CsCl melt $\mathrm{R}_{\mathrm{Cm}-\mathrm{Cl}}$ was around $0.270 \mathrm{~nm}$ and varying the temperature (from 550 to $750{ }^{\circ} \mathrm{C}$ ) did not have any noticeable effect on the value of $\mathrm{R}_{\mathrm{Cm}-\mathrm{Cl}}$. The values of $\mathrm{Cm}-\mathrm{Cl}$ distance obtained here agree well with the results reported for molten $\mathrm{Cs}_{2} \mathrm{NaCmCl}_{6}$ at $830{ }^{\circ} \mathrm{C}, 0.272 \mathrm{~nm}$ and for the solutions of $\mathrm{CmCl}_{3}$ in $8.7-12.3 \mathrm{M} \mathrm{LiCl}$ at room temperature, $0.275-0.276 \mathrm{~nm}(9,11)$. For comparison, in solid $\mathrm{Cs}_{2} \mathrm{NaCmCl}_{6}$ at $680{ }^{\circ} \mathrm{C} \mathrm{R} \mathrm{Rm}_{\mathrm{Cl}}=0.268 \mathrm{~nm}(11)$. 
$\underline{\text { Reaction of } \mathrm{Cm}(\mathrm{III}) \text { species with oxide ions }}$

To study the effect of oxygen on speciation of curium(III) in fused alkali chlorides, a melt containing $0.045 \mathrm{~mol} / 1$ of $\mathrm{CmCl}_{6}{ }^{3-}$ in $\mathrm{NaCl}-2 \mathrm{CsCl}$ at $550{ }^{\circ} \mathrm{C}$ was sparged with chlorine-oxygen mixtures. The partial pressure of $\mathrm{O}_{2}$ was gradually (in ten successive steps) increased from 0.0250 to 0.9937 atm, and the bubbling tube was made of silica. Unfortunately chlorine dissolved in the melt prevented measuring reasonable quality spectra below $480 \mathrm{~nm}$ due to high absorbance, even when the partial pressure of $\mathrm{Cl}_{2}$ was as low as 0.0063 atm. After the melt was sparged with argon (to remove dissolved chlorine) a spectrum could be recorded and that contained a peak at around $360 \mathrm{~nm}$ not previously present, Figure 3.

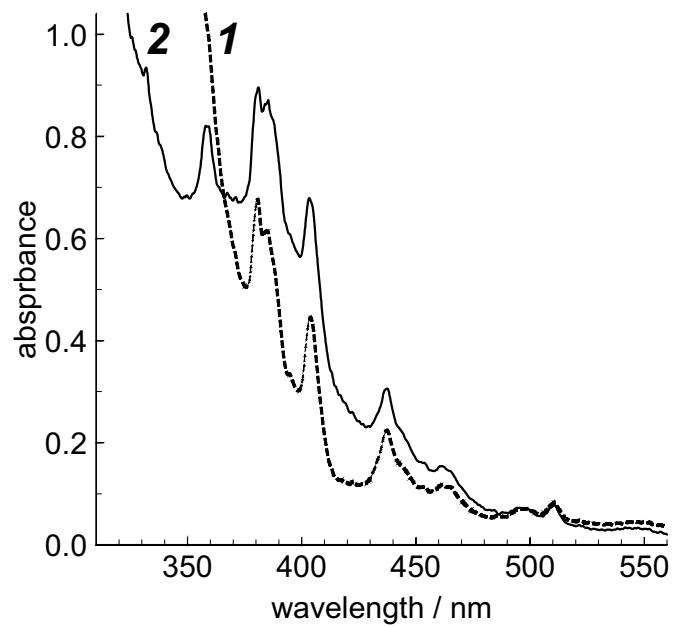

Figure 3. EAS of $\mathrm{Cm}(\mathrm{III})$ in $\mathrm{NaCl}-2 \mathrm{CsCl}$ Figure 4. Effect of adding barium oxide on eutectic melt at $550{ }^{\circ} \mathrm{C}$ before (line 1) and EAS of $\mathrm{Cm}$ (III) in $\mathrm{NaCl}-2 \mathrm{CsCl}$ eutectic after (line 2) sparging the melt with $\mathrm{Cl}_{2}-\mathrm{O}_{2}$ gas mixtures.

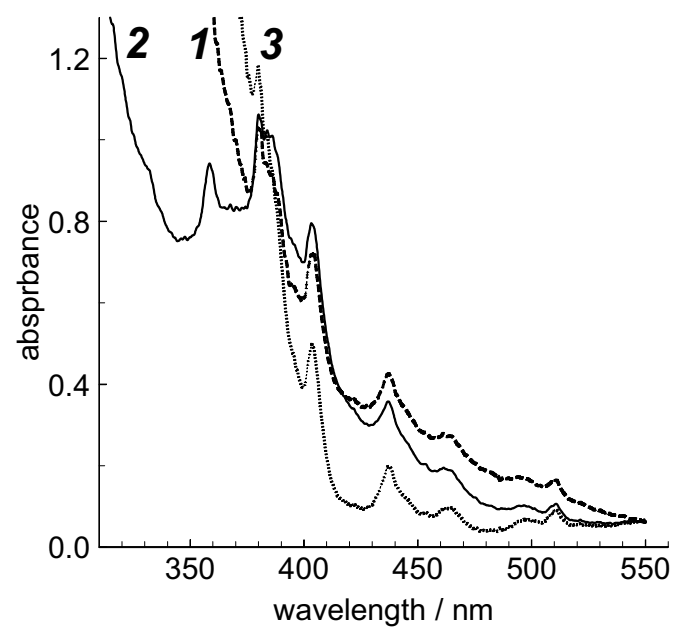

melt at $550{ }^{\circ} \mathrm{C}$ : starting melt (line 1); after adding $\mathrm{BaO}$ and bubbling $\mathrm{Cl}_{2}$ followed by Ar through a silica tube (line 2); and after bubbling $\mathrm{Cl}_{2}$ followed by $\mathrm{Ar}$ through a graphite tube (line 3).

Another method of introducing oxygen species into the melt was addition of barium oxide. After adding $0.010 \mathrm{~g}$ of $\mathrm{BaO}$ to a $\mathrm{NaCl}-2 \mathrm{CsCl}$ melt containing $0.156 \mathrm{~g}$ of $\mathrm{CmCl}_{3}$ the resulted mixture was held for 30 min and then the turbid melt was sparged with $\mathrm{Cl}_{2}$ for $15 \mathrm{~min}$ followed by argon for another $15 \mathrm{~min}$. Chlorine and argon were bubbled through a silica capillary tube dipped into the melt. After such manipulation the spectrum of the starting melt (line 1 in Figure 4) changed and a well defined peak around $360 \mathrm{~nm}$ appeared (line 2 in Figure 4). Resulting melt was further sparged with $\mathrm{Cl}_{2}$ for 15 min but this time the gas supplying tube was made of graphite. After removing excess dissolved chlorine by bubbling argon for $15 \mathrm{~min}$ through the melt the spectrum recorded (line 3 in Figure 4) closely resembled that of the starting $\mathrm{CmCl}_{6}{ }^{3-}$ containing melt and the peak at $360 \mathrm{~nm}$ was no longer present.

Thus the new peak around $360 \mathrm{~nm}$ in the EAS of curium containing melts appears after $\mathrm{O}^{2-}$ ions are introduced into the system. This peak remains unchanged after the melt is sparged with gaseous chlorine supplied through a silica tube but disappears if $\mathrm{Cl}_{2}$ is 
bubbled through a graphite tube. This peak cannot be ascribed to the transitions in $\mathrm{CmCl}_{6}{ }^{3-}$ ion. The absorption spectrum of $\mathrm{Cm}^{3+}$ aqueous acidic solutions contains a band at $352 \mathrm{~nm}$ originating from ${ }^{8} \mathrm{~S}_{7 / 2} \rightarrow{ }^{6} \mathrm{D}_{7 / 2}$ transition but the intensity of this band is very low (the oscillator strength is $c a .50$ times below that of the band at $395 \mathrm{~nm}$ ) (8). The peak appearing in the spectra of chloride melts at $360 \mathrm{~nm}$ is currently ascribed to the soluble curium(III) oxychloride formed by the reaction [1], and the following reactions describe its behavior in the presence of chlorine:

$$
\begin{gathered}
\mathrm{CmO}^{+}+\mathrm{Cl}_{2} \rightarrow \text { no reaction } \\
2 \mathrm{CmO}^{+}+2 \mathrm{Cl}_{2}+\mathrm{C} \rightarrow 2 \mathrm{Cm}^{3+}+\mathrm{CO}_{2}+4 \mathrm{Cl}^{-}
\end{gathered}
$$

The EAS of the melts containing $\mathrm{Cm}$ (III) chloro-species and the proposed $\mathrm{CmO}^{+}$ions (with background and the charge transfer band subtracted) are compared in Figure 5.

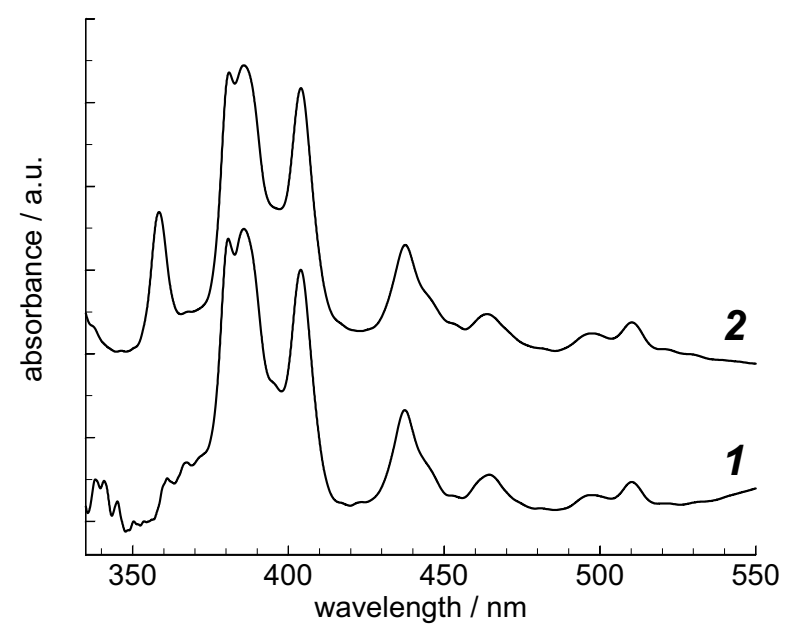

Figure 5. Electronic absorption spectra of $\mathrm{NaCl}-2 \mathrm{CsCl}$ melt containing $\mathrm{Cm}$ (III) species before (line 1) and after (line 2) introducing oxide ions, $550{ }^{\circ} \mathrm{C}$.

For a more detailed study of the behavior of curium(III) species in chloride melts in the presence of $\mathrm{O}^{2-}$ ions the concentration of the oxide ions in the melt was varied by bubbling through the melt $\mathrm{Ar}-\mathrm{HCl}-\mathrm{H}_{2} \mathrm{O}$ gas mixtures with different partial pressures of the components. The equilibrium of the reaction [4] depends on the ratio of partial pressures of $\mathrm{HCl}$ and $\mathrm{H}_{2} \mathrm{O}$. In the present work the value of $\log \left(p_{\mathrm{HCl}}^{2} / p_{\mathrm{H}_{2} \mathrm{O}}\right)$ in the gas mixtures was varied between 0.5 and -10.6.

Bubbling Ar- $\mathrm{HCl}-\mathrm{H}_{2} \mathrm{O}$ gas mixtures through the $3 \mathrm{LiCl}-2 \mathrm{KCl}$ eutectic containing $\mathrm{CmCl}_{3}$ at $450{ }^{\circ} \mathrm{C}$ resulted in gradual changes in the EAS as the partial pressure of water increased, Figure 6. The absorbance below $400 \mathrm{~nm}$ decreased and a peak around $360 \mathrm{~nm}$ appeared. From the known value of the equilibrium constant for the reaction [4]:

$$
K=\frac{p_{H C l}^{2} \cdot\left[\mathrm{O}^{2-}\right]}{p_{\mathrm{H}_{2} \mathrm{O}} \cdot\left[C l^{-}\right]^{2}}
$$

the concentration of the oxide ions in the melt can be estimated. For $3 \mathrm{LiCl}-2 \mathrm{KCl}$ melt at $450{ }^{\circ} \mathrm{C} K$ equals to $c a$. $10.29-10.33$ (13-15). 


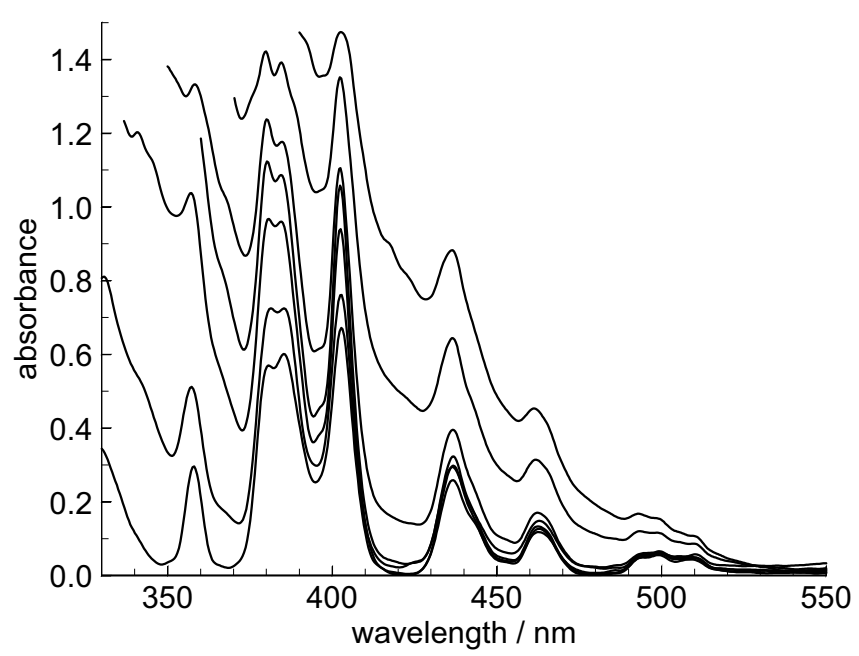

Figure 6. Changes in the EAS of $3 \mathrm{LiCl}-2 \mathrm{KCl}$ melt containing $\mathrm{Cm}(\mathrm{III})$ species after bubbling Ar-HCl- $\mathrm{H}_{2} \mathrm{O}$ gas mixtures at $450{ }^{\circ} \mathrm{C}$. Values of $\log \left(p_{\mathrm{HCl}}^{2} / p_{\mathrm{H}_{2} \mathrm{O}}\right)$ in the gas phase (top to bottom): $0.49,-1.31,-2.31,-3.31,-4.47,-5.38$ and -6.39 . Starting Cm(III) concentration $0.158 \mathrm{~mol} / \mathrm{l}$.

After the value of $\log \left(p_{\mathrm{HCl}}^{2} / p_{\mathrm{H}_{2} \mathrm{O}}\right)$ dropped below -5.4 (corresponding to $\mathrm{p}\left[\mathrm{O}^{2-}\right]$ value below 5) some solid phase started to form in the melt. This was detected from the growing background in the spectra in the entire wavelength region. This solid is currently attributed to curium oxide (reaction [2]) although it cannot be excluded that the solubility of $\mathrm{CmOCl}$ was exceeded and the excess of oxychloride precipitated. When the final melt with $\left.\mathrm{p}^{2-} \mathrm{O}^{2-}\right]$ around unity was sparged with chlorine using a graphite tube all the solids were dissolved, the peak at $c a .360 \mathrm{~nm}$ disappeared and the EAS returned to the initial state (upper line in Figure 6). The relative amounts of different curium species were estimated from the results of the spectroscopy measurements and the results are presented in Figure 7.

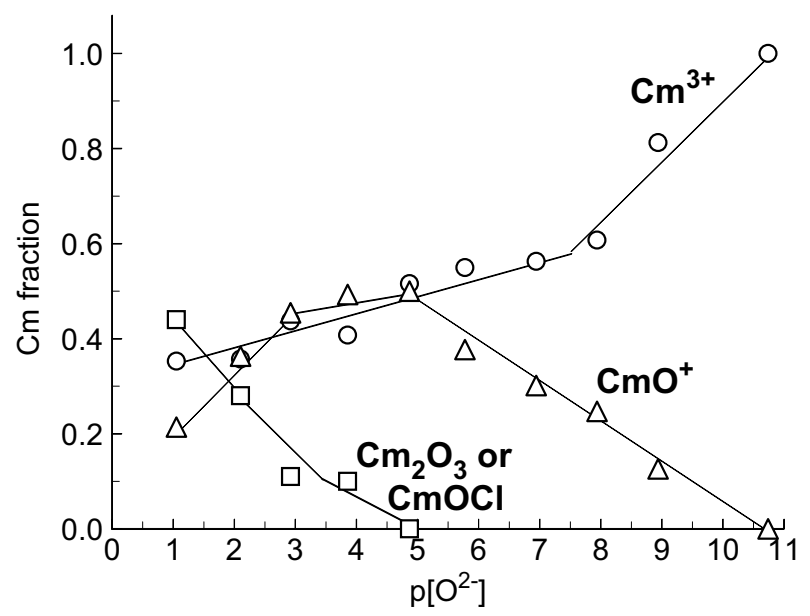

Figure 7. Distribution of curium between various species in $3 \mathrm{LiCl}-2 \mathrm{KCl}$ melt at $450{ }^{\circ} \mathrm{C}$ estimated from the results of EAS measurements at various compositions of the gaseous mixture $\left(\mathrm{Ar}-\mathrm{HCl}-\mathrm{H}_{2} \mathrm{O}\right)$ bubbled through the melt. Total molar fraction of $\mathrm{Cm}$ in the melt is 0.0059 . 
Changes in the EAS of curium containing NaCl-2CsCl melts during bubbling Ar$\mathrm{HCl}-\mathrm{H}_{2} \mathrm{O}$ mixtures at 550,650 and $750{ }^{\circ} \mathrm{C}$ were similar to those observed in $3 \mathrm{LiCl}-2 \mathrm{KCl}$ eutectic. An example of the spectra recorded at $550{ }^{\circ} \mathrm{C}$ is given in Figure 8. At all the temperatures studied a peak around $360 \mathrm{~nm}$ appeared as the partial pressure of $\mathrm{H}_{2} \mathrm{O}$ in the gas mixture increased and that peak disappeared after chlorine was bubbled through the melt using a graphite tube or a silica tube with a graphite thread suspended inside.

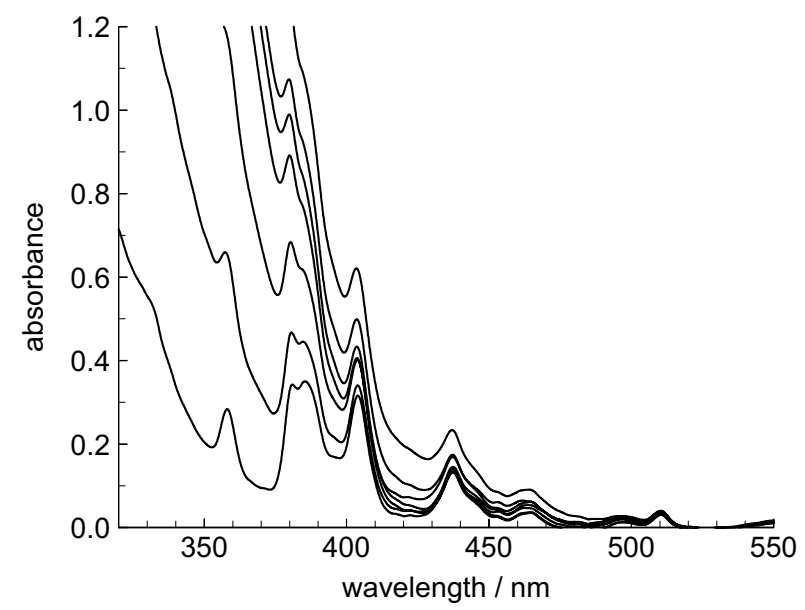

Figure 8. Changes in the EAS of $\mathrm{NaCl}-2 \mathrm{CsCl}$ melt containing $\mathrm{Cm}(\mathrm{III})$ species after bubbling Ar-HCl- $\mathrm{H}_{2} \mathrm{O}$ gas mixtures at $550{ }^{\circ} \mathrm{C}$. Values of $\log \left(p_{\mathrm{HCl}}^{2} / p_{\mathrm{H}_{2} \mathrm{O}}\right)$ in the gas phase (top to bottom): $-1.4,-2.1,-2.9,-3.6,-4.3,-5.0$ and -5.7 . Starting Cm(III) concentration $0.115 \mathrm{~mol} / 1$.

There is no data on the equilibrium constant for the reaction [4] in $\mathrm{NaCl}-2 \mathrm{CsCl}$ melts to enable calculation of the oxide ions concentration in the melt. Analysis of intensities of the absorption peaks in the EAS shows that in $\mathrm{NaCl}-2 \mathrm{CsCl}$ melt the concentration of $\mathrm{Cm}^{3+}$ ions initially decreased, then leveled off. Concentration of $\mathrm{CmO}^{+}$mirrored that of $\mathrm{Cm}^{+}$. No formation of a solid precipitate was noted. The preliminary results concerning distribution of curium species in $\mathrm{NaCl}-2 \mathrm{CsCl}$ melt at various ratios of $\mathrm{HCl}$ and $\mathrm{H}_{2} \mathrm{O}$ in the gas phase are presented in Figure 9.

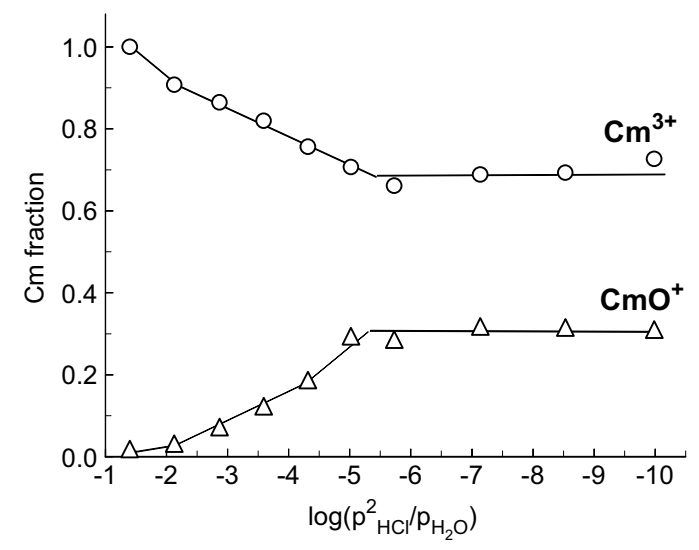

Figure 9. Distribution of curium between various species in $\mathrm{NaCl}-2 \mathrm{CsCl}$ melt at $550{ }^{\circ} \mathrm{C}$ obtained from the results of EAS measurements at various compositions of the gaseous mixture $\left(\mathrm{Ar}-\mathrm{HCl}-\mathrm{H}_{2} \mathrm{O}\right)$ bubbled through the melt. Total molar fraction of $\mathrm{Cm}$ in the melt is 0.0058 . 


\section{Conclusions}

The electronic absorption spectra of curium(III) chloro-species, $\mathrm{CmCl}_{6}{ }^{3-}$, were recorded in chloride melts based on $3 \mathrm{LiCl}-2 \mathrm{KCl}$ and $\mathrm{NaCl}-2 \mathrm{CsCl}$ eutectics between 450 and $750{ }^{\circ} \mathrm{C}$. The absorption bands in the spectra arise from the electronic transitions from the ground ${ }^{8} \mathrm{~S}_{7 / 2}$ state. The $\mathrm{Cm}-\mathrm{Cl}$ distance estimated from the results of spectroscopy measurements is $2.75 \AA$ in $3 \mathrm{LiCl}-2 \mathrm{KCl}$ melt and $2.70 \AA$ in $\mathrm{NaCl}-2 \mathrm{CsCl}$ melt. In the presence of oxide species (added to the melt by dissolving barium oxide or by bubbling $\mathrm{Cl}_{2}-\mathrm{O}_{2}$ or Ar-HCl- $\mathrm{H}_{2} \mathrm{O}$ gas mixtures) the absorbance below $400 \mathrm{~nm}$ decreases and a new peak (tentatively attributed here to the soluble curium oxychloride) around $360 \mathrm{~nm}$ appears. This peak becomes more pronounced as the concentration of $\mathrm{O}^{2-}$ in the melt increases. Bubbling pure $\mathrm{Cl}_{2}$ through the melt does not affect this peak but in the presence of carbon (e.g., using a graphite tube for introducing $\mathrm{Cl}_{2}$ into the melt) the absorption peak around $360 \mathrm{~nm}$ disappears. The results of the spectroscopy measurements were applied here to obtain some preliminary estimates of curium species distribution in alkali chloride melts depending on the concentration of oxide ions.

\section{References}

1. A. Osipenko, A. Maershin, V. Smolenski, A. Novoselova, M. Kormilitsyn and A. Bychkov, J. Nucl. Mater., 396, 102 (2010).

2. J. R. Peterson, J. Inorg. Nucl. Chem., 34, 1603 (1972).

3. A. G. Osipenko, A. A. Mayorshin and A. V. Bychkov, Radiochim. Acta, 97, 227 (2008).

4. G. J. Lumetta, M. C. Thompson, R. A. Penneman and P. G. Eller, in The Chemistry of the Actinide and Transactinide Elements, L. R. Morss, N. M. Edelstein and J. Fuger, Editors, Vol. 3, p. 1397, Springer, Dordrecht (2008).

5. W. T. Carnall, P. R. Fields, D. C. Stewart and T. K. Keenan, J. Inorg. Nucl. Chem., 6, 213 (1958).

6. L.B. Asprey and T.K. Keenan, J. Inorg. Nucl. Chem., 7, 27 (1958).

7. W. T. Carnall and P. R. Fields, J. Am. Chem. Soc., 81, 4445 (1959).

8. W. T. Carnali and K. Rajnak, J. Chem. Phys., 63, 3510 (1975).

9. P. G. Allen, J. J. Bucher, D. K. Shuh, N. M. Edelstein, and I. Craig, Inorg. Chem., 39, 595 (2000).

10. Yu. A. Barbanel, V. P. Kotlin and V. V. Kolin, Radiokhimiya, 19, 497 (1977) (in Russian); Sov. Radiochem., 19, 406 (1977).

11. Yu. A. Barbanel, Coordination Chemistry of f-elements in Melts, p. 120, Energoatomizdat, Moscow (1985) (in Russian).

12. Ibid., p. 113.

13. G. S. Picard, F. Seon and B. Tremillon, J. Electroanal. Chem., 102, 65 (1979).

14. R. Lisy and R. Combes, J. Electroanal. Chem., 83, 287 (1977).

15. Y. Castrillejo, M. R. Bermejo, E. Barrado, A. M. Martinez and P. Diaz Arocas, J. Electroanal. Chem., 545, 141 (2003). 